that the logic of his position is that only a handful of students will benefit from what he regards as true university education, whether in the sciences or the humanities. Only a few can be taught face-to-face by tutors who know them and are prepared to discuss their work with them in detail. Others will need technical expertise, or perhaps preliminary training, before going on to law school, business school or medical school, or into employment. This would entail a distinction, acknowledged or otherwise, between true universities, essentially suitable for only a minority, and training colleges, rather like the original distinction between universities and polytechnics (a distinction which is now defunct in the United Kingdom). It would also entail a distinction between academically indulgent institutions, with high and general educational aims, and functional institutions with precise practical goals, expected to give clear value for money. The likelihood is that public funding would be available only for the latter. But perhaps Douglas would not mind. Rightly or wrongly, the United Kingdom has just turned its back on this kind of dichotomy. For the time being, all universities are supposed to be equal.

There is, however, one further question, in my view the most fundamental of all, to which Douglas's answer is unclear. What is the ideal relation between teaching and research? He blames professors for taking their research too seriously, and palming off their teaching on their juniors. But he does not suggest any means to reverse this practice. In the United Kingdom it begins to look increasingly as if research, especially scientific research, will come to be based in a few selected universities, undergraduate teaching being the main responsibility of the rest. Graduate students will presumably find their way to the research universities, to be supervised by those actively engaged in research. Undergraduates will thus be taught by professional teachers, as they were at school The teaching institutions will become, in effect, tertiary schools ('schools with ash-trays', as someone has called them). Professors will no longer incur blame for not caring about undergraduates, because they will have no undergraduates to care about in their research-orientated lives. Things may well come to this. When they do, I shall almost feel inclined to join Douglas in his nostalgia for the old days at Oxford and Cambridge, though I feel sure, as he apparently does not, that those days are over (and in any case, they were ncver perhaps quite so glorious as he assumes).

Baroness Warnock is at Brick House, Axford, Wiltshire SN8 2EX, UK.

\section{Unreasonable ambition}

Ernest Gellner

Irrationality: The Enemy Within. By Stuart Sutherland. Constable: 1992. Pp. 357. £14.95.

STUART Sutherland is a rationalist. So, as it happens, am I. So you might expect me to acclaim an author who expresses views, attitudes and values very much akin to my own, and who does it with verve, eloquence, coherence and in good, clear prose. In fact, however, this book leaves me feeling very uneasy. Why do I not salute an intellectual friend and ally? Why the reservations about this survey of modern follies and their causes?

Let us go straight to the heart of the matter. Sutherland is not merely a rationalist, he is also a psychologist. Moreover, although he is clearly a highly intelligent and able member of the species, the trouble is that he is also, in his basic attitude, a fairly typical one. Scratch an anthropologist and you'll find a philosopher, and sometimes even one with a sense of history; sociologists sometimes have the same merits; but psychologists, seldom. Scratch a psychologist, and you'll generally find a man eager to flee the humanities and act up to a certain conventional model of a scientist. I'm not sure this is true of all the other books of Sutherland's, notably Breakdown, which was highly personal, but it is true of this one.

It isn't that I in any way disapprove of Sutherland's aspiration to expose irrational behaviour: my worries spring rather from the fear that he has greatly underestimated the difficulties of the task. The underlying assumption of this book is that its subject's opposite, reason, is easy to identify. It is, as Spinoza said about truth, the touchstone both of itself and of its error. It is readily available, luminous and obvious, and so is unreason. I do not know whether Sutherland would plead guilty to this accusation when so spelt out, but its influence on his argument, at any rate in this book, is evident from the terrible clarity of the battle lines: he can spot unreason so very clearly; he knows his enemy, because he also knows, with disturbing and facile confidence, how to identify our position, rationality. Neither poses any problems for him, really.

His conception of rational thought and conduct owes a great deal to basic statistical ideas and to the economists' conception of sensible market behaviour. Rational man is careful in his handling of evidence, avoids well-known fallacies and rigidity and sheep-like behaviour, and his lucidity in making inferences from the database at his disposal is matched by his clarity about his aims and the assessment of what will serve them best. Clearly he is an enlightened individualist who will not follow a multitude to commit folly.

An admirable ideal, and I share Sutherland's admiration. But the book contains no serious discussion of the social and historical preconditions of the emergence of this strange animal, or any sense of his untypicality, in wider historical context. The index does not contain the name of Max Weber or of any of those who have been puzzled by the emergence of rationality, not even that of James Frazer (whose views on this topic were not so far from Sutherland's, though he had far more sense of my feeling for the poetry of unreason). The disaggregation of the world into isolable elements that can then be subjected to statistically proper interpretations, the disaggregation of conduct into isolable and freely chosen aims permitting costbenefit calculations - all this is the achievement of one type of society, it is not inherent in the human condition. It is not part of our birthright. Like believers in a Revelation who condemn to hellfire those who preceded it and had no access to it, Sutherland's ideal implicitly condemns much of mankind to servitude to unreason. Perhaps he would say that there is no point in deploring that which is beyond remedy, but the problem is not perceived.

But the situation isn't all that simple even among us, where reason is an important though not exclusive norm. Another obvious name missing from the index is that of Thomas Kuhn. Without accepting everything in the work of this philosopher, it is difficult to dispute his main claim about the nature of science: namely that, except in the course of major revolutions, science works and can only work through a kind of socially, culturally induced dogmatism, a prejudgement of major and objectively contentious issues, the imposition of a shared paradigm. If this is true among scientists working in a milieu disconnected from their social identity and its pressures, and in the main imbued by an individualistic-rationalistic spirit, how much truer it must be of ordinary life and its strategies, which are Sutherland's concern! To put it another way: the data at our disposal do not uniquely dictate what we should think about our environment. Far from it. Theories, as the phrase goes, are under-determined by facts. There is simply far too much slack between evidence and conclusion: unreason, sheep-like thinking, rigidity, call it what you will, must take up this slack.

To say all this is not to ask Sutherland 
to write a different book from the one he set out to write. He has indeed taken our current notion of rationality for granted, without probing deep into its basis, and gives us an interesting survey of the violations of this norm. But he also aspires to go further: at the end of the book, he offers a list of the hindrances to rationality, which by implication seek out its roots. The list runs as follows: our evolutionary heritage, our neurological equipment, laziness, ignorance of statistics and self-serving behaviour. A curiously heterogeneous set of basic sins. .

Apart from lacking historical sense in broad outline, the author is exceedingly slapdash in handling specific facts. He likes to invoke examples of military folly, but tends to get it wrong. On page 41, the Light Brigade in the Crimea is described as charging Turkish (sic) guns and soldiers. Lord Raglan may indeed have been "doltish" but he could tell enemies from allies. Sutherland seems to have little sense of geography: if the Turks had indeed been the enemy, how on earth could the expedition have ever passed through the Dardanelles and reached the Black Sea? On page 144, General Montgomery is similarly derided for failing to take Antwerp in 1944 , thereby enabling the German 23rd Army to escape from northern Holland (sic) and help defend Arnhem. The Germans had no need to escape from northern Holland (they stayed there, undisturbed, until the end of the war), and even less need of Antwerp to reach Arnhem from there, as Antwerp is nowhere near the way from north Holland to Arnhem. (Sutherland means northern Belgium.) Those soldiers may be fools but they do occasionally consult the map. The ends of each chapter of the book contains pithy advice on how to avoid folly. I commend one addition: when telling stories about the folly of others, check your own account for howlers.

All the same, this is a lively and readable book about modern follies, even if it fails to tackle the harder questions about the role of reason and unreason in human society and the human psyche.

Ernest Gellner is at King's College, Cambridge CB2 1ST, UK.

\section{3 review supplements}

Nature's review supplements next year are Spring Books (15 April), Autumn Books (25 November) and New Journals (7 October). The latter will cover journals launched during or after June 1991 with at least four separate numbers issued by the end of April 1993.
La neige d'antan

Walter Gratzer

C. P. Snow and the Struggle of Modernity. By John de la Mothe. University of Texas Press: 1992. Pp. 288. \$35.

WHEN the first laboratories sprang up in Victorian Oxford, the wife of the Warden of All Souls observed with contempt: "The Warden could get up science in a fortnight if he wanted to". Seventy or so years later, so C. P. Snow tells us, the mathematician G. H. Hardy reflected: "It's rather odd, but when we hear about

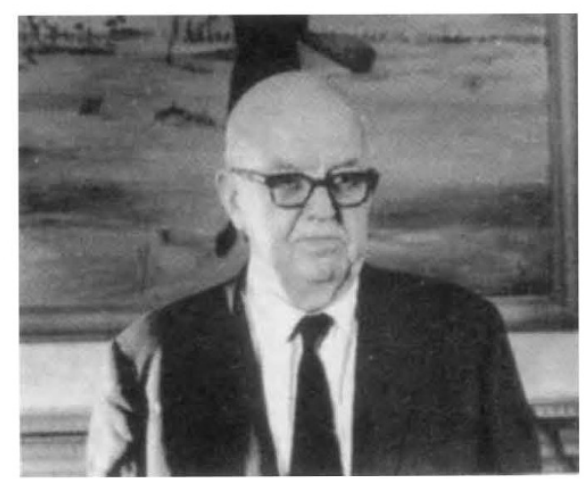

Snow - poor spokesman for science.

'intellectuals' nowadays, it doesn't include people like me and J. J. Thomson and Rutherford". Snow's career as writer and magus was rooted in his indignation at such affronts to the first of his chosen callings. He vociferated it loudly and often: "Not to have read War and Peace and La Cousine Bette and La Chartreuse de Parme [in the original no doubt] is not to be educated, but so is not to have a glimmer of the Second Law of Thermodynamics." It was probably the intolerable reek of humbug that so got up the noses of F. R. Leavis and other literati of the day and whipped them into such passions of wrath.

I happened to be at Harvard when Snow, just then at the peak of his unaccountable fame, came to deliver the Godkin lectures (later published as Science and Government). His audience, mainly of students from Harvard and MIT, filled a theatre the size of a baseball stadium, and he basked in their adulation. Many had already sent off for his collected oeuvre, bound in imitation morocco with genuine 18-carat gold-leaf lettering. Here, plainly, was the stuff of future $\mathrm{PhD}$ theses.

But that was 30 years ago, and I had not supposed that anyone bothered too much with Snow any more: yet now John de la Mothe has dished up for us his densely written and minutely researched treatise, bearing on the dust flap beneath the portentous title the familiar image of Lord Snow of The Two Cul- tures, turning on the world the morose gaze of a costive bulldog. "The discourse of modernity is comprised of a cacophony of voices, the interpretation of which can only be described as a struggle." Thus de la Mothe, getting his book off to an unenticing start. More, "it should not be surprising that our aspiration to more precisely delineate the parameters of this struggle has become the paradigmatic idea of our age." Well include me out when it comes to delineating parameters. Fighting down an urgent desire to bolt for cover, I ploughed on through the waterlogged terrain, feeling dry ground underfoot only when de la Mothe began to concern himself with Snow's life and especially his erratic scientific career.

De la Mothe identifies Snow with the thrust towards social progress and intellectual liberation - modernity, as he calls it - and while by no means uncritical of his subject, he accepts him substantially at Snow's own valuation of himself as the Messiah of the scientific age, both in his didactic utterances (the Rede and the Godkin lectures) and in his novels. These of course are peopled almost exclusively by scientists and academics and political mandarins, who stalk the Corridors of Power, gravid with the authority of their creator's years as scientist, civil servant and (briefly) politician. Science and Government purports to be a documentary study of decisionmaking processes in government, but as Snow remarks of his main protagonists, the deplorable Frederick Lindemann (Lord Cherwell) and Henry Tizard, they made the novelist's fingers itch; and Snow scratched where it itched (which, it must be conceded, makes the story an entertaining read, just as the novels often are).

Snow claims for scientists unique access to a wordly wisdom that few would arrogate to themselves (let alone their colleagues). They have, he asserted, "the future in their bones", a faculty denied by implication to members of other professions. To my mind, he was a poor spokesman for our trade. As a novelist he was pretty good for a scientist, as a scientist better at least than most novelists and as a politician merely, by all accounts, a failure. Lewis Eliot, the narrator of the roman fleuve, Strangers and Brothers, though a lawyer, is Snow himself - supercompetent, knowing and superior, the reflection in Narcissus's mirror. What undoubtedly lends spice to the novels is that we can identify (for Snow made no attempt to conceal them) the models for the characters, and to a certain extent the events also touch on reality. The trouble is that for all the solemn air of authority in which his characters envelop themselves, their aspirations are for the most part essen- 